\title{
AN ERRORS ANALYSIS IN TRANSFORMING ACTIVE TO PASIVE FORM OF INDRAPRASTA PGRI STUDENTS (VISUAL COMMUNICATION DESIGN PROGRAMME)
}

\author{
Fitria Iswari \\ Universitas Indraprasta PGRI \\ Jakarta, Indonesia \\ fitriaiswari@gmail.com
}

\begin{abstract}
English is the international language that is studied from elementary school to university level. In Universitas indraprasta PGRI, students get the English subject in first year, and one of material is passive voice form. From the students score in examination, the result is they had low score in transforming active to passive form. From that condition the writer do a research of an errors analysis in transforming Active to Passive form. The purpose of the research is to find the errors of students in transforming active to passive form. This is descriptive qualitative research which the data collection is gotten from test and interview. The data shows there are 428 errors in transforming active to passive voice from 4 classes randomly. From the data analysis, it can be taken a conclusion that students did all types of errors (omission, addition, misformation, misordering). From 4 classes there are 428 errors that they had made. And the highest errors are omission which is 134 errors, and the lowest errors are misformation which is 83 Errors. Misordering is 91 errors and addition is 120 errors. From the interview the writer got that students do not know the tenses of active voice so they cannot change rightly to passive voice.
\end{abstract}

Key words: errors analysis, transforming, active voice, passive voice.

\section{INTRODUCTION}

Language is a communication tool to deliver the massage. Language can be in spoken and written that both of them deliver the message or idea. Most of countries use English, because English is an international language, and English in Indonesia as a foreign language has important position. It makes it is studied by all students in every level and exists in subject from Elementary school to higher education level. In teaching and learning processes of English, there are four skills must be mastered, they are listening, speaking, reading, and writing.

As academician writing skill is a skill that must be mastered besides listening, reading, and speaking skill. Student in university level cannot avoid a writing activity, because they have to make task, article, and research as final task and those activities ask them to write. Writing is one of complex activity, because someone must have idea, knowledge to express their ideas and feelings in writing. Based on Nunan 
(2003:88) explained writing is the work of inventing ideas, thinking about how to express them, and organizing them into statements and paragraphs that will be clear to a reader. In other words, the sentences must have correct pattern to deliver the correct message.

In higher education English is one of subject that must be taken by students. In Indraprasta PGRI, especially students who take visual communication design program will get General English subject in the first year. Most all material in General English Subject discusses about Grammar, and passive voice is one of material that should be studied by students and will be tested on the final examination, but the result of the test is far of satisfying. The students often got low score. It is the background what the writer want to do a research of passive voice.

In the fact most of Foreign language students found the difficulty when they were studying grammar. according to some previous research researcher found some errors on students' work, for example the research that was conducted by Ildhias Pratiwi Putri has a title" AN ANALYSIS OF STUDENTS' GRAMMATICAL ERROR IN USING PASSIVE VOICE AT GRADE TEN OF SMA PERSADA
BANDAR LAMPUNG 2014 “, She found The total of error from 25 students' works, the researcher finds 436 total errors The total of error from 25 students' works, the researcher finds 436 total errors. More over the research was done by H.AbdulQodir, he found four categories of errors, and present continuous tense in passive voice form got the highest number in errors. More over according the data from writer, students' score of passive voice material is low. They have to make an error in transforming active to passive voice form. Based on the explanation above, this research aims to find the errors of the students' work in transforming active to passive voice form. The result of the research will be used as resource to improve the system or teaching learning process.

Most of foreign or L2 learner do some errors in leaning the target language. Brown (2000:217) also defined error as "a noticeable deviation from the adult grammar of the native speaker, reflects the competence of the learner". Hubard, et.al (1983:134). adds the definition about error that -Errors caused by lack of knowledge about the target language (English) or by incorrect hypotheses about it. The concept is the same to Crystal $(1987: 112)$ who says that error analysis is a technique for 
identifying, classifying and systematically interpreting the unacceptable forms produced. Based on the expert explanation of error, by someone learning a foreign language, using any of the principles and procedures provided by linguistics. So error is mistakes that are made because of lack of knowledge and understanding.

Find and identify the reason, types of the error is useful. In line to Ellis (2003:15) discusses the good reasons for focusing on errors as follow:

a. Errors are a conspicuous feature of learner language, raising important question of „Why do learners make errors?

b. It is useful for teachers to know what errors learners make.

c. It is possible that making errors may actually help learners to learn when they self-correct the errors they make.

There are some categories errors that were explained by Dulay et.al (1982:154155), they are:

(1) Omission means that an item which must be present in a well-formed utterance is absent.

(2) Additions are the second category of surface strategy taxonomy and also the opposite of omission. The characteristic for additions are divided into three categories: (b) regularization

(c) simple addition

(3) Misformation refers to "the use of the wrong form of the morpheme or structure.

(4) Misordering is the inccorect placement of the morpheme or goup of morpheme in an utterance.

\section{ACTIVE VOICE}

There are 2 voices in English; they are active and passive voice. Active voice occurs when a verb form shows that the subject has done something (Murthy, 2003:286).

Example: Mia swept the floor last night.

In a sentence there are two kinds of sentence, they are transitive and intransitive. The transitive sentence is a sentence where the verb can be followed by an object, example: My Mom reads a novel, and intransitive sentence is a sentence where the sentence does not need an object or without an object. For example: I scream hardly. One of the rules the sentence can be transformed in passive voice is the sentence has an object.
(a) double markings 
Table 1. Active voice form

Active

\begin{tabular}{|c|c|}
\hline Simple present & Mary helps the boy \\
\hline Present progressive & Marry is helping the boy \\
\hline Present perfect & $\begin{array}{l}\text { Marry has helped the } \\
\text { boy }\end{array}$ \\
\hline Simple past & Marry helped the boy \\
\hline Past progressive & $\begin{array}{l}\text { Marry was helped the } \\
\text { boy }\end{array}$ \\
\hline Past perfect & $\begin{array}{l}\text { Marry had helped the } \\
\text { boy }\end{array}$ \\
\hline Simple future & Marry will help the boy \\
\hline Be going to & $\begin{array}{l}\text { Marry is going to help } \\
\text { the boy }\end{array}$ \\
\hline Future perfect & $\begin{array}{l}\text { Marry will have helped } \\
\text { the boy }\end{array}$ \\
\hline
\end{tabular}

Source : Azzar (1999:208)

\section{PASSIVE VOICE}

In some cases, the using of passive voice is to emphasize the object rather than the agent/doer in an activity. Azar (2006:211) suggests, "The passive is most frequently used when it is not known or not important to know exactly who performs an action." for example: the mosque was built in 1980. More over Marcella Frank(1972: 67) explained that the passive voice is preferred when the "doer" of an action (or the agent)is unimportant or unknown. The passive voice commonly found in the text books, in scientific technical or business report. In academic writing, the sentences can be written both Active and Passive voice, it depends on the purposes and cases. Corson and Smollett (2014) suggest that passive might be used in some cases, they are:

1. The actor is unknown:

Muhajirin Mosque was built in1980 
2. The actor is irrelevant

3. You want to be vague about who is responsible 4. You are talking about a general truth

5. You want to emphasize the person or thing acted on.

6. You are writing in a scientific genre that traditionally relies on passive voice.

The rules to transform active to passive one, the sentence must have transitive (verbs that can be followed by an object) verb. According to Murthy (2003:286) mentioned that there are six rules in passive voice.

1. A sentence can be separated into subject, verb, and object.

Table 1. Active and passive Voice

\begin{tabular}{l|l} 
& Fortive \\
\hline $\begin{array}{l}\text { Simple } \\
\text { present } \\
\text { Present } \\
\text { progressive } \\
\text { Present } \\
\text { perfect }\end{array}$ & Mary helps the boy \\
$\begin{array}{l}\text { Simple past } \\
\text { Marry is helping the boy }\end{array}$ & Marry has helped the boy \\
$\begin{array}{l}\text { progressive } \\
\text { Past }\end{array}$ & Marry was helped the boy \\
\end{tabular}

Example : Fitria bought a book

2. The object of the sentence must be turned into subject.

3. The "be" form must be used according to the tenses of the verb.

4. Past Participle of the verb must be used

5. Preposition "by" must be added. In some cases it can be added if you think that it is important to know who performs the action.

6. The subject must be made the object.

Passive voice also has a formula for each tense. Here are the transforming active voice to passive that written by Azar.

helped by

The boy v by Marry

The boy $\mathrm{i}$ helped by The boy been help
ThFubtoyreis helped Byarry will have helped the boy maperfect

The boy is SoubeingAzzar (1999:208) helped by marry

The boy has been helped by marry

The boy was helped by Marry

The boy was being helped by Marry

The boy had been 


\section{METHODOLOGY}

The writer uses descriptive qualitative research. This research is aim to find the real phenomenon where writer wants to find the errors of transforming active voice to passive one. Not only finding the errors but also finding the reason in making errors. According to Sugiono (2005:21). Descriptive method is a method that to describe or analyze the finding of the research but not using to take broader conclusion. in line with

According to Ary (2010:29): "Qualitative researches seek to understand a phenomenon by focusing on the total picture rather than breaking it down into variables.

The data is taken from students of Indraprasta PGRI majoring Visual Communication Design (DKV) Program. There are 40 students will do test and interview. The data collection is taken from students' score and the result of interview. The writer uses test and question list in interview. There are some steps in this research: preparing, collecting the data, and analyzing.

In preparing step, writer prepares the question. Because of the writer is a lecturer in the classroom and the passive voice is one of the material, so the writer teach the material first then take the test.
In collecting data, writer will take test and interview. The test is taken to know the students' ability on passive voice material. According to Arikunto (2010:193) Test is an examination or trial to measure skill, intelligency, and attitude of individual or group. It means the test is the instrument to collect valid data. The test will be taken after the lecturer explained the material about passive voice then in the next meeting students will have test in transforming active to passive voice. There are 10 sentences in various tenses and in active voice form that will be transformed by students in passive voice form. Next collecting data process is to take information through interview. There are 10 open questions about the students and the passive voice. The writer uses the open question to get the deep answer from the students. Suprapto (2013:42) said "A characteristic from interview in the qualitative research is used questions that answer about narrative and contain about probing questions.

The last step is analyzing the data. The score will be describing through the table and diagram to make reader easy to read. The data will identify, describe, and explain the errors, how much the errors, and the causes. 
Volume 3 No. 1, February 2020

P-ISSN 2623-0062

Universitas Banten Jaya

E-ISSN 2622-9056

\section{FINDING AND DISCUSSION}

Table 2. The students score of passive voice test

\begin{tabular}{|c|c|c|c|c|}
\hline No & Omission & Addition & Misformation & Misordering \\
\hline 1 & 5 & 5 & 2 & 1 \\
\hline 2 & 2 & 4 & 0 & 2 \\
\hline 3 & 5 & 5 & 0 & 1 \\
\hline 4 & 6 & 6 & 7 & 2 \\
\hline 5 & 2 & 2 & 3 & 4 \\
\hline 6 & 3 & 3 & 1 & 4 \\
\hline 7 & 4 & 5 & 2 & 6 \\
\hline 8 & 5 & 1 & 1 & 7 \\
\hline 9 & 6 & 3 & 4 & 1 \\
\hline 10 & 0 & 7 & 2 & 2 \\
\hline 11 & 2 & 3 & 1 & 3 \\
\hline 12 & 7 & 2 & 4 & 0 \\
\hline 13 & 8 & 2 & 1 & 0 \\
\hline 14 & 7 & 2 & 0 & 1 \\
\hline 15 & 3 & 2 & 0 & 2 \\
\hline 16 & 4 & 2 & 5 & 3 \\
\hline 17 & 3 & 2 & 2 & 4 \\
\hline 18 & 2 & 6 & 3 & 2 \\
\hline 19 & 9 & 6 & 4 & 1 \\
\hline 20 & 4 & 2 & 0 & 7 \\
\hline 21 & 8 & 10 & 1 & 1 \\
\hline 22 & 9 & 3 & 2 & 2 \\
\hline 23 & 3 & 2 & 1 & 3 \\
\hline 24 & 3 & 6 & 1 & 2 \\
\hline 25 & 2 & 3 & 1 & 2 \\
\hline 26 & 2 & 1 & 0 & 7 \\
\hline 27 & 5 & 1 & 2 & 0 \\
\hline 28 & 2 & 3 & 1 & 0 \\
\hline 29 & 2 & 3 & 1 & 1 \\
\hline 30 & 2 & 2 & 4 & 3 \\
\hline 31 & 1 & 1 & 3 & 1 \\
\hline 32 & 1 & 1 & 2 & 2 \\
\hline 33 & 1 & 5 & 2 & 1 \\
\hline 34 & 0 & 2 & 6 & 3 \\
\hline 35 & 0 & 2 & 4 & 1 \\
\hline 36 & 0 & 2 & 4 & 5 \\
\hline 37 & 2 & 0 & 4 & 2 \\
\hline 38 & 1 & 0 & 0 & 2 \\
\hline 39 & 1 & 0 & 1 & 0 \\
\hline
\end{tabular}




\begin{tabular}{c|c|c|c|c}
40 & 2 & 3 & 1 & 0 \\
Total & 134 & 120 & 83 & 91
\end{tabular}

The table above describes the score that students got from the test. The test is taken from 4 classes randomly. The amount of errors from 4 classes is 428 errors. The highest errors is the Omission errors which 234 errors in the classroom, and the lowest errors is misformation which 83 errors.

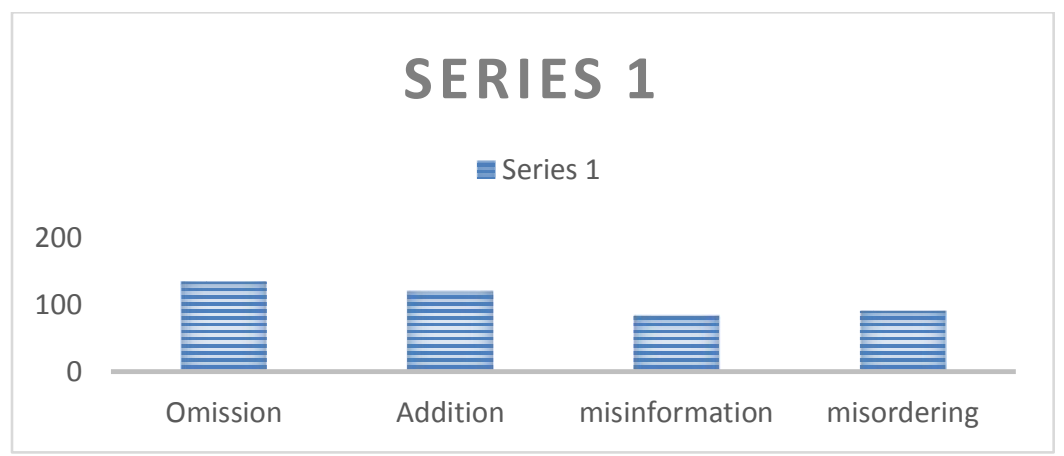

Diagram1. Recapitulation of Students Errors in passive Voice

The explanation of the diagram is almost the same with the table. From diagram we know the highest score of making errors is omission Errors and the lowest one is misinformation errors. From the data above tells that the errors of transforming active to passive voice are high.

\section{Analysis}

The analysis theory is from Dulay who categorized errors in (1) omission, (2) additions, (3) misformation, and (4) misordering.

1. Omission.
In omission the item must be in well form. But in here students omitted them.

Omitting -ed in regular form:

- Television is watch by Him every day.

Omiting to be auxiliary.

- Those papers have not handed by Irwan and arief ( omitting the been)

- The final exam being studied by students (omitting is)

- $\quad$ The lesson is going to explaining by lecturer. (omitting be) 
- Agus will invited by Johan to his wedding next month ( omitting be)

\section{Additions}

In addition error students added the item that must not appear.

Additing "being"

- The lesson is being going to explained by lecturer.

Additing "verb-ing"

- The lesson is going to explaining by lecturer.

3. Misformation errors are the using of the wrong form of the morpheme or structure.

Misformation the "verb". In this case students make errors in verbs and auxiliary.

- The lesson is going to be explain by lecturer.

- Those papers has handed by Irwan and arief

4. Misordering errors is the inccorect placement of the morpheme or goup of morpheme in an utterance.

Misordering "not"

- Those papers have been not handed by Irwan and arief.

- All passengers are being not helping by the cabin crew.

\section{Interview}

From interview writer found some reasons of the high errors score in transforming active to passive voice. From the interview it can be taken conclude:

1. Students do not know the tenses of active voice, so they make error in transforming in passive voice.

2. Some students do not know the past participle verb.

3. Students forget the form of passive voice.

4. Students feel shy if asking use English in the classroom. It makes them wont to ask something to the lecturer.

\section{CONCLUSION}

From the data analysis, it can be taken a conclusion that students did all types of errors. From 4 classes there are 428 errors that they had made. And the highest errors are omission which is 134 errors. And the lowest errors are mis information which is 83 Errors. The number of errors that made by students is high. From the interview we can see that almost students do not know the form both active and passive voice. It makes 
they cannot change the form active to passive. The condition because lecturer doesn't emphasize in passive voice form because of lack of time and a lot of the material.

\section{REFERENCES}

Arikunto,Suharsimi.(2010).Prosedur Penelitian.Yogyakarta :Rineka Cipta

Ary, Donald. (2010). Introduction to Research in Education. Eighth edition. Canada: Thomson Wadworth

Azar, Betty Schrampfer. (1999). Understanding and Using English Grammar, 3th Edition. United State of America: Longman.

Azar, Schrampfer, Betty.(2006) Understanding and Using english Grammar. Third edition. Englewood Cliffs, New Jersey: Prentice Hall, Inc.

Brown, H.Douglas. (2000) Principles of Language Learning and Teaching, 4th ed. New York: Longman.

Corson, Tim and Rebecca Smollett. Passive Voice: When to Use It and When to Avoid It. University College Writing Centre. Diakses Pada Minggu, 30 November 2014 http://www.writing.utoronto.ca/advice /style-and-editing/passive-voice

Crystal, David. (1987). The Cambridge encyclopedia of language .Cambridge: University Press

Dulay, Heidi.(1982). Language Two. New York: Oxford University Press.

Ellis.(2003) Second Language Acquisition. New York: Oxford Univerity Press.

Hubard, Peter, et.al. (1983). A Training Course for TEFL. New York: Oxford University Press.

Ildhias Pratiwi Putri. An Analysis of students Grammatical error in Using passive
Voice at Grade ten of Sma Persada Bandar lampung 2014. The 3rd InternationalMultidiciplinary

Conference on Social Sciences (IMCoSS 2015)Bandar Lampung University (UBL). Diakses Pada 19 Januari 2020

Murthy, Jayanthi Dakshina.(2003).

Contemporary English Grammar.

New Delhi: Book Palace

Nunan, David.( 2003). Practical English Language Teaching. McGraw-Hill: Harper Collins Publisher.

Qodir, H.A. (2006), An Error Analysis on Changing Active Voice Into Passive Voice. Journal HIMMAH . VII No. 18 Januari - April 2006. Diakses Pada 13 Januari 2020

Suprapto, (2013), Metode Penelitian Ilmu Pendidikan dan Ilmu ilmu Pengetahuan Sosial, Yogyakarta: Center for Academic Publishing Service. 